REPORT

\title{
The utility of tumour necrosis factor blockade in orphan diseases
}

\section{E C Keystone}

Ann Rheum Dis 2004;63(Suppl II):ii79-ii83. doi: 10.1136/ard.2004.028498

A variety of rheumatic disorders have been successfully treated with tumour necrosis factor (TNF) blockers. However, TNF blockade may be useful in a number of rare diseases. Preliminary data suggest that several forms of vasculitis appear responsive to TNF antagonists-Behçet's disease, Churg-Strauss vasculitis, polyarteritis nodosa, and giant cell arteritis, among others. Wegener's granulomatosis and sarcoidosis have been shown to improve with infliximab but not with etanercept. These results lend further support for the concept of differential mechanism(s) of action of the two antagonists with infliximab being more effective for the treatment of granulomatous diseases. Polymyositis/dermatomyositis may also be responsive to TNF blockade. TNF likely plays little role in Sjögren's syndrome as evidenced by the lack of efficacy of both TNF antagonists. Etanercept has been shown to be useful in the treatment of hepatitis $C$ both in reducing the viral load and improving liver function. A number of other more rare disorders also may be responsive to TNF blockade. Further studies with larger numbers of well characterised patients and treatment regimens are necessary to provide more definitive evidence of the utility of the TNF antagonists in these serious and often life threatening diseases.

$\mathrm{T}$ mour necrosis factor (TNF) blockade has been used successfully to treat a number of rheumatic disorders that have a substantial burden of illness, disorders such as rheumatoid arthritis, psoriatic arthritis, ankylosing spondylitis, and other seronegative arthropathies. There are, however, a variety of diseases that effect the musculoskeletal system whose prevalence is less than $1 / 1000$ - the so called orphan diseases-in which TNF blockade appears promising. The purpose of this paper is to review recent data concerning the utility of TNF blockade in several orphan disorders including primary Sjögren's syndrome, polymyositis, vasculitis, sarcoidosis, and hepatitis C.

A number of caveats must be considered to properly interpret the data on "orphan" diseases. Most of the studies, with a few exceptions, are open label studies, generally with a few patients and of short duration. As well, the studies often involve single centres and use poorly validated outcome measures.

\section{PRIMARY SJÖGREN'S SYNDROME}

TNF along with a variety of other cytokines is thought to play a key role in the pathogenesis of Sjögren's syndrome. Thus, $\mathrm{TNF} \alpha$ is expressed in minor salivary gland duct cells of patients with Sjögren's syndrome. ${ }^{1-4}$ TNF $\alpha$ has been demonstrated to induce expression of endothelial adhesion molecules, release matrix metalloproteinases from glandular epithelial cells, and promote the influx of mononuclear cells into the salivary glands. ${ }^{5}{ }^{6}$ In vitro studies have demonstrated prevention of acinar cell destruction by blocking TNF $\alpha$ induced matrix metalloproteinases. The role of TNF in Sjögren's syndrome is also supported by an animal model of Sjögren's syndrome in which pegylated recombinant human TNF Rl prevented lymphocyte infiltration into the lacrimal and salivary glands as well as autoimmunity. ${ }^{7}$

Infliximab was initially shown to be effective in a single centre, open label pilot study of 16 patients with active primary Sjögren's syndrome. Three infusions of infliximab ( $3 \mathrm{mg} / \mathrm{kg}$ ) were given with assessments out to 24 weeks. ${ }^{8}$ Statistically significant improvement was demonstrated in all clinical and functional parameters including global assessments, erythrocyte sedimentation rate, salivary flow rate, Schirmer's I test, tender joint count, fatigue, dry eyes, and dry mouth. No adverse events were noted including anti-double stranded DNA and a lupus-like syndrome. To confirm these results a multicentre randomised double blind study of 103 patients with Sjögren's syndrome was conducted with infliximab infused at $5 \mathrm{mg} / \mathrm{kg}$ at week 0,2 , and 6 versus placebo. ${ }^{9}$ At entry, patients had to have more than $50 \mathrm{~mm}$ on two out of three visual analogue scales (VAS) including joint pain, fatigue, and dryness of buccal, ocular, skin, and vaginal regions as well as sicca symptoms. The results demonstrated no difference in the percentage of patients meeting response criteria at weeks 10 and 22. Additional analyses revealed no difference from placebo in the proportion of patients with a $30 \%$ decrease on one VAS, or those with a $30 \%$ decrease on the sicca VAS. No differences were observed in salivary gland flow rates, Schirmer's tests, or C-reactive protein.

A pilot study evaluated the effect of etanercept $(25 \mathrm{mg}$ subcutaneously twice a week) in an open label study of 15 patients with well defined primary Sjögren's syndrome. ${ }^{10}$ The patients were examined initially for 12 weeks with follow up to 24 weeks. Etanercept did not reduce the sicca symptoms and signs although severe fatigue was reduced in a subgroup of four patients with Sjögren's syndrome. Minor salivary gland biopsy results were unchanged. The results suggest that short term use of infliximab or etanercept is unhelpful in the treatment of primary Sjögren's syndrome. Further long term studies are needed to more completely rule out the utility of TNF blockade in Sjögren's syndrome.

\section{POLYMYOSITIS/DERMATOMYOSITIS}

Several studies have indicated a prominent role for TNF $\alpha$ in the pathogenesis of dermatomyositis and polymyositis. ${ }^{11-15}$ Two patients who were corticosteroid naive were treated with infliximab $10 \mathrm{mg} / \mathrm{kg}$ every two weeks for three doses and evaluated at 12 weeks. ${ }^{11}$ Within one week after therapy, improvement in pain and malaise was reported with marked improvement in creatine phosphokinase (CPK) muscle

Abbreviations: BVAS, Birmingham Vasculitis Activity Score; GCA giant cell arteritis; TNF, tumour necrosis factor; VAS, visual analogue scale 
strength observed by 12 weeks. Repeat muscle biopsy at week 4 revealed a reduction in the extent of infiltrate and number of necrotic muscle fields in both patients. In another study, four patients with myositis refractory to a variety of immunosuppressives were treated with etanercept. ${ }^{12}$ There was a $50 \%$ reduction in CPK with improved symptoms/signs.

One other patient refractory to five courses of intravenous pulsed steroids, methotrexate (30 mg weekly), and prednisone $(60 \mathrm{mg})$ alone and in combination with azathioprine $(150 \mathrm{mg})$ responded dramatically to five courses of infliximab ( $10 \mathrm{mg} / \mathrm{kg}$ ) infused over two weeks with normalisation of CPK. ${ }^{13}$ Improvement was sustained despite reduction in oral corticosteroids and discontinuation of azathioprine.

\section{VASCULITIS \\ Wegener's granulomatosis}

$\mathrm{TNF} \alpha$ has been implicated in the pathogenesis of Wegener's granulomatosis. Elevated levels of plasma $T N F \alpha$ have been shown to correlate with active glomerulonephritis and elevated in vitro TNF stimulated peripheral blood mononuclear cells and CD4+ T cells. ${ }^{16}$ Strong in situ TNF $\alpha$ expression has been demonstrated in infiltrating mononuclear cells and in the epithelial cells of Bowman's capsule in active renal lesions. ${ }^{17}$ Increased serum neopterin, soluble p55 TNF receptor, and elevated soluble interleukin-2 receptor levels have been observed in patients, which correlated with cell mediated immune activation. ${ }^{18}$

The first report of etanercept therapy in Wegener's granulomatosis described an open label study of 20 patients with persistently active Wegener's or patients with a new disease flare in whom etanercept $25 \mathrm{mg}$ subcutaneously twice a week was added to current therapies. ${ }^{19}$ Etanercept was the only new therapy in 14 patients. The therapies were adjusted as medically indicated. Baseline characteristics demonstrated upper respiratory involvement in $80 \%$ of patients, pulmonary in $20 \%$, and glomerulonephritis in $10 \%$. The results showed that $95 \%$ of patients completed six months. VAS of Wegener's granulomatosis improved from 3.6 at baseline to 0.6 , while the prednisone dose was reduced from $12.9 \mathrm{mg} /$ day to $6.4 \mathrm{mg} /$ day. In $75 \%$ of patients the VAS at consecutive visits was increased from baseline with severe flares occurring in three patients. A subsequent 12 month double blind randomised controlled trial of etanercept in 180 patients with Wegener's granulomatosis revealed no difference in flare rate between the etanercept and placebo groups (Stone et al, unpublished observations). The results suggest no role for etanercept in the treatment of Wegener's granulomatosis.

A total of 16 patients (in three separate reports) with Wegener's granulomatosis were treated with 3-5 mg infliximab for 3-26 months mainly in addition to other immunosuppressive therapy. ${ }^{20-22}$ Complete or partial remission was achieved in most of the patients with substantial reduction in the Birmingham Vasculitis Activity Score (BVAS). However, two studies of infliximab in Wegener's granulomatosis revealed that treatment was complicated by severe infection. In one six month open label trial of 10 patients, infliximab was added to cyclophosphamide $(2 \mathrm{mg} / \mathrm{kg})$ and prednisone $(0.5 \mathrm{mg} / \mathrm{kg})$. The study was terminated early because of serious infections despite variable dosing regimens. ${ }^{23}$ Complete remission was achieved by six months in all patients with sustained immunosuppression for more than one year. Two patients experienced severe infections including one who died from Pneumocystis carinii pneumonia. In a second study, 30 patients with vasculitis associated with antineutrophilic cytoplasmic antibodies were treated with infliximab $5 \mathrm{mg} / \mathrm{kg}$ plus cyclophosphamide and corticosteroids followed by methotrexate. Although there was an $88 \%$ remission rate by 6.5 weeks, there were seven serious infections and a high relapse rate. ${ }^{24}$ Taken together the results suggest that infliximab is effective in Wegener's granulomatosis, but should not be combined with cyclophosphamide based on the high risk of infection.

\section{Behçet's disease}

Behçet's disease is thought to be mediated by a variety of cytokines, including TNF $\alpha$ released from Th 1 lymphocytes. ${ }^{25}$ Patients with active disease demonstrate increased numbers of monocytes and Tlymphocytes expressing $\gamma \delta$ receptors that overproduce TNF $\alpha$. Patients also show increased levels of circulating TNF $\alpha$ and soluble receptors. ${ }^{26}{ }^{27}$ High TNF $\alpha$ levels are observed in the aqueous humour from patients with uveitis associated with Behçet's. ${ }^{28}$

To date, a total of approximately 55 patients refractory to conventional therapy (including high dose corticosteroids, azathioprine, and ciclosporin) have been treated with TNF $\alpha$ antagonists, predominately infliximab in doses of $3-5 \mathrm{mg} / \mathrm{kg}$ using a conventional induction regimen. ${ }^{29-38}$ Most patients were treated primarily for ocular disease although patients with gastrointestinal, vascular, articular, and mucocutaneous lesions and central nervous system involvement have also been treated.

Several small case series and case reports of the use of infliximab in Behçet's disease have been published, whereas the effect of etanercept has only been presented at conferences. ${ }^{29-38}$ Results of therapeutic studies suggest that infliximab is highly effective in inducing short term remission of virtually all manifestations of disease including sight threatening panuveitis. In cases of ocular inflammation, remission was observed in some within 24 hours and marked improvement of visual acuity in others by seven days. Infliximab was used in doses of 3-5 $\mathrm{mg} / \mathrm{kg}$ with continuous treatment every two months for as long as two years in some patients. Complete remission has been maintained with reduction in concomitant immunosuppressive therapy. Continuous therapy has been used in most reports, but a few patients have remained in remission for up to 12 months off treatment. Other patients have flared on discontinuing infliximab with improvement on reinstitution of therapy.

As noted above, there are few published data on the use of etanercept in Behçet's disease. However, a four week randomised placebo controlled trial of etanercept in mucocutaneous disease demonstrated a beneficial effect on skin lesions and arthritis within the first week of treatment. ${ }^{34}$ The patients treated with etanercept had a $40 \%$ chance of remaining free of oral ulcers at the end of treatment compared with a $5 \%$ chance in the placebo group. In some patients symptoms recurred three months after etanercept was discontinued. In another study by the same investigators, addition of etanercept to previous therapy in patients with severe ocular inflammation demonstrated a beneficial effect of maintaining visual acuity. However, the effect was not sustained in the six months after discontinuation of therapy (reviewed in reference 35). Whether infliximab is more effective than etanercept in the treatment of Behçet's disease remains unclear, although infliximab was shown to be beneficial in several patients who were unresponsive to etanercept. At least one patient was shown to be responsive to adalimumab.

\section{Giant cell arteritis}

Granulomatous vasculitis has been demonstrated in giant cell arteritis (GCA), Wegener's granulomatosis, and Takayasu's arteritis. All have prominent tissue macrophage infiltration where excess TNF $\alpha$ production has been demonstrated. ${ }^{39}$

Several case reports have indicated that infliximab $(3-5 \mathrm{mg} / \mathrm{kg}$ ) was beneficial in the treatment of temporal 
arteritis. In a report of five patients, of four patients with corticosteroid resistant GCA three showed improvement with infliximab. ${ }^{40}$ In the other two patients, infliximab was shown to be effective as initial therapy with dramatic improvement. However, the improvement could not be sustained after three infusions. ${ }^{41}$ Patients receiving infliximab improved within two weeks enabling corticosteroid reduction within two weeks to two months. The patients who received anti-TNF therapy were followed up for a mean of $\sim 25$ years with continued disease remission while receiving continuous therapy for $\sim 1.5$ years. Etanercept was shown to be beneficial as a steroid sparing agent in a patient with corticosteroid resistant GCA. ${ }^{42}$

TNF antagonists have also been evaluated in polymyalgia rheumatica (PMR). In a pilot study, infliximab $3 \mathrm{mg} / \mathrm{kg}$ was administered at week 2 and 6 in four patients with relapsing PMR in whom steroids could not be reduced below $7.5 \mathrm{mg} /$ day and who had multiple vertebral fractures. Three of the four patients had complete and persistent remission with normal C-reactive protein/erythrocyte sedimentation rate at the end of one year's follow up. ${ }^{43}$

Patients with Takayasu's arteritis have also been treated with TNF $\alpha$ antagonists. An open label study of 15 patients with active relapsing Takayasu's arteritis mostly resistant to conventional therapy was carried out with etanercept $(n=7)$ and/or infliximab $(\mathrm{n}=11)^{44} ; 67 \%$ of patients $(10 / 15)$ sustained remission without development of new magnetic resonance imaging (MRI) lesions, remaining off corticosteroid therapy. In $27 \%$ of patients (4/15) partial remission was seen and they were able to discontinue corticosteroid therapy. Repeat MRI imaging in these patients demonstrated new vascular lesions over 14 months of anti-TNF therapy. In 50\% of responders remission was sustained by an increase in the dose of anti-TNF therapy. Three patients switched from etanercept to infliximab. The results suggest the need for a randomised controlled study.

\section{Polyarteritis}

Three patients with relapsing microscopic polyangiitis refractory to corticosteroids and an immunosuppressive medication were treated with infliximab monthly for three months. ${ }^{45}$ Improvement was demonstrated by reductions on the BVAS and corticosteroid reduction. Three patients with ChurgStrauss vasculitis who failed corticosteroid and cyclophosphamide therapy were treated with etanercept $(n=1)$ or infliximab $(n=2)$. The patient treated with etanercept achieved remission, while the patients treated with infliximab achieved partial remission or failed to progress. An additional patient with childhood polyarteritis nodosa showed improvement in clinical and laboratory measures after treatment with infliximab. ${ }^{46}$

\section{SARCOIDOSIS}

Sarcoidosis is a systemic granulomatous disorder of unknown origin in which alveolar macrophage derived $\mathrm{TNF} \alpha$ participates in the induction and maintenance of granulomas. ${ }^{47}$ High levels of TNF $\alpha$ released from alveolar macrophages seem to be associated with disease progression. ${ }^{48}$ Moreover, spontaneous release of TNF $\alpha$ by alveolar macrophages is greater in patients with active disease than in patients with inactive or corticosteroid treated disease.

A prospective open label study of etanercept was undertaken in 17 patients with stage II/III pulmonary sarcoidosis in which extrapulmonary and immunosuppressive therapy were excluded. The study was terminated early at 15 months for lack of effect with improvement in five patients, worsening in 11 patients, and withdrawal of one patient. ${ }^{49}$ TNF levels in serum and bronchioalveolar lavage or alveolar macrophages failed to predict a response. Serious adverse events included one lymphoma and one plasmacytoma. Etanercept was also evaluated in a blinded randomised placebo controlled trial of 20 patients with methotrexate refractory ocular sarcoidosis. ${ }^{50}$ No difference was observed between the outcomes of patients treated with etanercept and placebo.

Infliximab has been evaluated in a total of 21 patients ${ }^{51-59}$ with multiorgan sarcoidosis refractory to conventional therapy. Patients were treated with $5 \mathrm{mg} / \mathrm{kg}$ and followed every six weeks up to 25 months, with continuous therapy. Infliximab induced rapid resolution of disease with relapse occurring on discontinuation.

The data suggest that sarcoidosis is responsive to infliximab but not to etanercept. The results are consistent with the differential effect of these two TNF antagonists in other granulomatous diseases.

\section{CHRONIC HEPATITIS C}

The use of etanercept in patients with chronic hepatitis $\mathrm{C}$ induced hepatitis has been evaluated. A 24 week randomised control trial of etanercept (25 mg subcutaneously twice a week) $(n=19)$ versus placebo $(n=25)$ was carried out in patients on a background of interferon and ribavirin. ${ }^{60}$ At 24 weeks, more patients receiving etanercept exhibited normal alanine aminotransferase (ALT) in the absence of serum HCV RNA. Thus $58 \%$ of patients treated with etanercept exhibited normal or absent ALT and HCV RNA levels compared with $28 \%$ of the placebo treated group. The data support the rationale for use of etanercept in hepatitis C induced hepatitis.

Infliximab has also been used in patients with rheumatic diseases who also have chronic hepatitis B and C. After more than one year of treatment, no worsening in liver function or virological status was observed. ${ }^{61}$ In contrast, a patient with positive hepatitis B virus surface antigen developed fulminant hepatitis two weeks after receiving a second infliximab infusion for the treatment of refractory adult onset Still's disease. $^{62}$

\section{MISCELLANEOUS CONDITIONS}

The utility of TNF $\alpha$ blockage has been demonstrated in a number of other conditions-some of which are less well known (table 1). A number of these rare conditions are associated with periodic fever including familial Hibernian fever, CINCA syndrome, and SAPHO syndrome. ${ }^{63} 64$

More recently, other conditions including acute and chronic graft versus host disease, myelodysplastic syndromes, and even acute herniated intervertebral disc disease have been shown to benefit from TNF blockade.

\section{SUMMARY AND CONCLUSIONS}

A number of issues still remain unresolved regarding the utility of TNF antagonists in orphan diseases. Questions relating to the optimal agent, the dosing regimen, including

Table 1 Miscellaneous conditions in which tumour necrosis factor blockade appears promising

\begin{tabular}{|c|c|}
\hline $\begin{array}{l}\text { SAPHO syndrome } \\
\text { Periodic fever } \\
\text { Relapsing polychondritis } \\
\text { Multicentric reticulohistiocytosis } \\
\text { Macrophage activation syndrome } \\
\text { Hyper-lgD syndrome } \\
\text { Familial Hibernian fever } \\
\text { Acute and chronic graft versus } \\
\text { host disease }\end{array}$ & $\begin{array}{l}\text { Pyoderma gangrenosum } \\
\text { PAPA syndrome } \\
\text { Cochleovestibular disorders } \\
\text { Cicatricial pemphigoid } \\
\text { Herniated intervertebral } \\
\text { disc disease } \\
\text { Amyloidosis } \\
\text { CINCA syndrome } \\
\text { Myelodysplastic syndrome }\end{array}$ \\
\hline
\end{tabular}


the need for long term maintenance therapy and safety issues related to use with the other immunosuppressants are just a few of the issues that need to be addressed. Larger, more well characterised case series are clearly needed.

Preliminary findings from the conditions evaluated may provide further insight into differential mechanism(s) of action of the TNF antagonists regarding monoclonal antibodies (that is, infliximab/adalimumab) versus the soluble receptor construct (etanercept). Responsiveness of granulomatous conditions such as Wegener's granulomatosis, Crohn's disease, sarcoidosis, and possibly GCA to infliximab and not etanercept likely relates to the increased risk of granulomatous infections (mycobacterial tuberculosis, histoplasmosis, etc) with infliximab compared with etanercept therapy. Further studies are needed to understand these differences not only in terms of the mechanisms of action of the agents, but also the pathogenic mechanisms underlying the disorders themselves.

Taken together, the results of studies on TNF blockade support its utility in sarcoidosis, several forms of vasculitis, and hepatitis C. The usefulness of the agents used for TNF blockade is still uncertain in myositis, scleroderma, and the more uncommon conditions studied. There does not appear to be a benefit, at least in short term studies, in patients with the primary Sjögren's syndrome.

Overall, TNF antagonists appear to be setting new therapeutic standards for a multitude of inflammatory orphan conditions. Confirmation of these preliminary data is eagerly awaited.

Conflict of interest: E Keystone has received research grants or served as consultant to or as member of the speakers' bureau sponsored by various companies that manufacture treatments for rheumatoid arthritis (Abbott Laboratories, Amgen, Astra Zeneca, Aventis Pharma, Biogen Inc, Bristol-Myers Squibb, Centocor Inc, Füisawa, Genetech, Glaxo Wellcome, Glycodesign, Hoffman-la Roche Ltd (Canada), Isis, Novartis Canada, Pfizer Canada, Pharmacia, QLT, Phototherapeutics Inc, Schering Plough Inc, Targeted Genetics, Therakos, Vertex Pharmaceuticals, Wyeth, Wyeth Ayerst).

Correspondence to: Professor E C Keystone, Department of Medicine, University of Toronto; and Division of Advanced Therapeutics, Rebecca MacDonald Centre for Arthritis and Autoimmune Disease, Mount Sinai Hospital, Joseph and Wolf Lebovic Building, 2nd Floor, 60 Murray Street, Toronto, Ontario, M5G 1X5, Canada; ksnow@mtsinai.on.ca

\section{REFERENCES}

1 Fox RI, Kang HI, Ando D, Abrams J, Pisa E, Cytohine M. RNA expression in salivary gland biopsies of Sjogren's syndrome. J Immunol 1994; 152:5532-9.

2 Koski H, Janin A, Humphreys-Beher MG, Sorsa T, Malmstrom M, Konttimen YT. Tumor necrosis factor $\alpha$ and receptors for it in labial salivary glands in Sjogren's syndrome. Clin Exp Rheumatol 2001;19:131-7.

3 Cauli A, Yanni G, Pitzalis C, Challacombe S, Panayi GS. Cytokine and adhesion molecule expression in the minor salivary glands of patients with Sïgren's syndrome and chronic sialoadenitis. Ann Rheum Dis 1994:54:209-15.

4 Sun D, Emmert-Buch MR, Fox PC. Differential cytokine mRNA expression in human labial minor salivary glands in primary Sjogrens syndrome. Autoimmunity 1998;28:125-37.

5 Azuma M, Motegi K, Aota K, Hayashi Y, Sato M. Role of cytokines in the destruction of acinar structure in Sjogrens syndrome salivary glands. Lab Invest 1997;77:269-80

6 Moser RB, Scheiffenbaum B, Groscurth P, Fehr J. Interleukin 1 and tumor necrosis factor stimulate human vascular endothelial cells to promote transendothelial neutrophil passage. J Clin Invest 1989;83:444-55.

7 Tornwald J, Fox H, Edwards C, Fox RI. Treatment with pegylated recombinant methionyl human soluble tumor necrosis-factor with type 1 receptor (PEGSTNF-R1) prevents development of Sjogrens syndrome and diabetes in the NOD mouse model. Arthritis Rheum 1999;42(suppl 9):S403.

8 Steinfeld SD, Demols P, Salmon I, Kiss R, Appleboom T. Infliximab in patients with primary Sjogren's syndrome: a pilot study. Arthritis Rheum 2001;44:2371-5

9 Mariette X, Ravaud P, Steinfeld S, Baron G, Goetz J, Huchulla E, et al. Inefficacy of infiximab in primary Sjogren's syndrome: results of the randomized controlled trial of remicade in primary Sjogren's (TRIPPS). Arthritis Rheum 2004;50:1270-6.
10 Zandbelt $M$, de Wilde $P$, Van Damme $P$, Hoyng $C B$, van de Putte $L B$, van den Hoogen F. Etanercept in the treatment of patients with primary Sjogren's syndrome: a pilot study. J Rheumatol 2004;31:96-101

11 Hengstman G, van den Hoogen FH, Barrera P, Netea MG, Pieterse A, van de Putte LBA, et al. Successful treatment of dermatomyositis with anti-tumor necrosis factor $\alpha$. Preliminary observations. Eur Neurol 2003;50:10-15.

12 Saadeyh C. Etanercept is effective in the treatment of polymyositis/ dermatomyositis which is refractory to conventional therapy. Arthritis Rheum 2000;43:S193.

13 Labioche E, Liozon B, Weschler B, Loustand-Ratti V, Soria P, Vidal E. Refractory polymyositis responding to infliximab: extensive follow up. Rheumatology 2004;43:531-2.

14 Nzeussseu A, Durez P, Houssiau F, et al. Successful use of infiximab in a case of refractory juvenile dermatomyositis. Arthritis Rheum 2001:44:590.

15 Miller M, Mendez E, Klein-Gitelman M, Pachman L. Use of etanercept in juvenile dermatomyositis. Arthritis Rheum 2002;46:MO766.

16 Ludviksson B, Sneller, Chua K, Talar-Williams C, Langford C, Ehrhardt R, et al. Active Wegener's granulomatosis is associated with HLA-DR4+ T cells exhibiting an unbalanced Th1-type T cell cytokine pattern: reversal with IL-10. $\mathrm{J}$ Immunol 1998; 160:3602-9.

17 Noronha I, Kruger C, Andrassy K, Ritz E, Waldherr R. In situ production of TNF-alpha, IL-1 beta and IL-2R in ANCA-positive glomerulonephritis. Kidney Int 1993:43:682-92.

18 Nassonov E, Samsonov M, Tilz G, Beketova T, Semenkova E, Baranov A, et al. Serum concentrations of neopterin, soluble interleukin 2 receptor, and soluble tumor necrosis factor receptor in Wegener's granulomatosis. J Rheumatol 1997:24:666-70.

19 Bedoos NM, Uhfelder ML, Hellmann DB, Crook S, Hoffman GS. Etanercept combined with conventional treatment in WG: A six month open-label trial to evaluate safety. Arthritis Rheum 2001;41:1149-54.

20 Lamprecht $\mathbf{P}$, Voswinkel J, Lilenthal T, Nolle B, Heller M, Gross WL, et al. Effectiveness of TNF alpha blockade with infliximab refractory Wegener's granulomatosis. Rheumatology 2002;11:1303-7.

21 Booth AD, Jefferson HS, Ayliffe W, Andrews PA, Jayne DR, et al. Safety and efficacy of TNF alpha blockade in relapsing vasculitis. Ann Rheum Dis 2002;61:559.

22 Bartolucci P, Ramanoelina J, Cohen P, Mahr A, Godmer P, Le Hello C, et al. Systemic vasculitides: an open label pilot study on 10 patients. Rheumatology 2002;41:1126-32.

23 Gause AM, Arbach O, Reinhold-Keller E, Lamprecht P, Voswinkel J, Gross WL, et al. Induction of remission with infliximab in active generalized Wegener's granulomatosis in effective but complicated by severe infections. Arthritis Rheum 48:S208, abstract 450.

24 Booth A, Harper L, Hammad T, Bacon P, Griffith M, Levy J, et al. Prospective study of TNF alpha blockade with infliximab in anti-neutrophil cytoplasmic antibody-associated systemic vasculitis. J Am Soc Nephrol 2004;15:717-21.

25 Gul A. Behçet's disease: an update on the pathogenesis. Clin Exp Rheumatol 2001;19(suppl 24):S6-S12.

26 Turban B, Gallasti H, Erdi G, Gurler A, Michel BA, Billliger PM. Systemic levers of the T cell regulatory cytokines IL-10 and IL-12 in Behcet's disease: soluble TNFR-75 as a biological marker of disease activity. J Rheumatol 1997;24:128-32.

27 Evereklioglu C, Er W, Turkoz Y, Cekmen M. Serum levels of TNF $\alpha$, SIL-2R, IL-6 and IL-8 are increased and associated elevated lipid peroxidation in patients with Behçet's disease. Mediators Inflamm 2002:11:87-93.

28 Santo Lacoma M, Martin C, Gallardo Galero JM, Collantes-Estevez E. Aqueous humor and serum tumor necrosis factor-alpha in clinical uveitis. Ophthal Res $2001 ; 33: 251-5$.

29 Sfikakis PP, Theodossiadis PG, Katsiari CG, Kaklamanis P, Markomichelakis NN. Effect of infliximab on sight threatening panuveitis in Behcet's disease. Lancet 2001;358:295-6.

30 Saulsburg FT, Mann JA. Treatment with infliximab for a child with Behcet's disease. Arthritis Rheum 2003;49:599-600.

31 Hassard PV, Binder SW, Nelson V, Vasiliauskas FA. Anti-tumor necrosis factor monoclonal antibody therapy for gastrointestinal Behcet's disease: a case report. Gastroenterology 2001;120:993.

32 Licata G, Pinto A, Tuttolomondo A, Banco A, Ciccia F, Ferrante A, et al. Antitumour necrosis factor alpha monoclonal antibody therapy for recalcitrant cerebral vasculitis in a patient with Behcet's syndrome. Ann Rheum Dis 2003:62:280-1.

33 Rozenbaum M, Rosner I, Portnoy E. Remission of Behcet's syndrome with TNF alpha blocking treatment. Ann Rheum Dis 2002;61:283-4.

34 Melikogllu M. Fresko I, Mat C, Yurkdakul S, Hamuryvdam V, Yazici H. Etanercept is beneficial in controlling the mucocutaneous lesions of Behcet's syndrome. Arthritis Rheum 2002;46: abstract 400.

35 Sfikakis PP. Behcet's disease: a new target for anti-tumour necrosis factor treatment. Ann Rheum Dis 2002;61 (suppl 2):ii51-ii53.

36 Joesph A, Raj D, Dua HS, Powell PT, Lawson PC, Powell RJ, et al. Infliximab in the treatment of refractory posterior uveitis. Ophthalmology 2003; 110:1449-53.

37 Suhler E, Smith J, Kurz D, Laver AK, Pickard TD, Rosenbaum JT. A prospective trial of infliximab therapy from patients with refractory uveitis: preliminary results. Arthritis Rheum 2003:48:S422.

38 Gulli S, Arrigo C, Bocchino L, Morgan TE, Sangari D, Castagna E, et al. Remission of Behcet's desease with anti-tumor necrosis factor monoclonal antibody therapy: a case report. BMC Musculoskelet Disord 2003;4:19.

39 Field M, Cook A, Gallagher G. Immunolocalisation of tumor necrosis factor and its receptors in temporal arteritis. Rheumatol Int 1997;17:113-18.

40 Cantini F, Niccoli L, Salvarani C, Pachula A, Olivieri I. Treatment of longstanding active giant cell arteritis with infliximab: report of four cases. Arthritis Rheum 2001:44:2933-5. 
41 Andonopoulos AP, Meimans N, Daoussis D, Bounas A, Giannopoulous G. Experience with infliximab (anti-TNF alpha monoclonal antibody) as monotherapy for giant cell arteritis. Ann Rheum Dis 2003;62:1116.

42 Tan A, Holdsworth J, Pease C, Emery P, McGonagal D. Successful treatment of resistant giant cell arteritis with etanercept. Ann Rheum Dis 2000;62:373-4.

43 Salvarani C, Cantini F, Niccoli L, Catanosa MG, Marcchioni P, Pulsatelli P, et al. Treatment of refractory polymyalgia rheumatica with infliximab: a pilot study. J Rheum 2003;30:760-3.

44 Hoffman G, Merkel P, Brassington R, Lenschow D, Kissin E, Liang G. Utility of anti-TNF therapy in Takayasu's arteritis. Arthritis Rheum 2003;48:5442.

45 Arbach 0, Gross WL, Gause A. Treatment of refractory Churg-Strauss Syndrome (CSS) by TNF alpha blockade. Immunobiology 2002;206:496-501

46 Whitney-Mahoney KJ, Parker S, Benseler S, Laxer R. The role of infliximab in a pediatric patient with polyarteritis nodosa. Arthritis Rheum 2003;48: abstract 455 .

47 Kunkel SL, Chensue SW, Strieter RM, Lynch JP, Remick DG. Cellular and molecular aspects of granulomatous inflammation. Am J Resp Cell Mol Biol 1989; 1:1439-47.

48 Ziegenhagen MW, Benner G, Zissel. Sarcoidosis TNF-alpha release from alveolar macrophages and serum level of IL-2R are prognostic markers. Am J Resp Crit Care Med 1997; 156:1586-98.

49 Utz JP, Limper AH, Kalra S, Specks U, Scott JP, Vuk-Pavlovic A, et al. Etanercept for the treatment of stage II and III progressive pulmonary sarcoidosis. Chest 2003;124:177-85.

50 Baughman RP, Bradley DA, Raymond IO, Lower EE, Kerr MA, Winget DB, et al. Double blind randomized trial of a tumor necrosis factor receptor antagonist (Etanercept) for treatment of chronic ocular sarcoidosis. Presented at the American Thoracic Society 2002; Abstract 917.

51 Ulbricht DU, Stoll M, Bierwkith J, Witte T, Schmidt RE. Successful tumor necrosis factor alpha blockade treatment in therapy-resistant sarcoidosis. Arthritis Rheum 2003:44:3542-3.

52 Baughman RP, lannuzzi M. Tumor necrosis factor in sarcoidosis and its potential for targeted therapy. BioDrugs 2003;17:425-31.
53 Roberts SD, Wilkes DS, Burgett RA, Knox KS. Refractory sarcoidosis responding to infliximab. Chest 2003;124:2028-31.

54 Baughmann RP, Lower EE, du Bois RM. Sarcoidosis. Lancet 2003:361:1111-18.

55 Serio RN. Infliximab treatment of sarcoidosis. Ann Pharmacother 2003;37:577-81

56 O'Connor TM, Shanahan F, Bredin CP. Infliximab therapy for complicated sarcoidosis. Ann Intern Med 2002;137:296-7.

57 Cook MC. Infliximab therapy for complicated sarcoidosis. Ann Intern Med 2002; 137:296-7.

58 Yee AM, Pochapin MB. Treatment of complicated sarcoidosis with infliximab anti-tumor necrosis factor-alpha treatment. Ann Intern Med 2001;135:27-31

59 Baughmann RP, Lower EE. Infliximab for refractory sarcoidosis. Sarcoidosis Vasc Diffuse Lung Dis 2001;18:70-4. Erraratum in Sarcoidosis Vasc Diffuse Lung Dis 2001;18:310.

60 Zein NN, Etanercept Study Group. A phase II randomized double blind, placebo controlled study of Tumor Necrosis Factor antagonist (Etanercept, Enbrel) as an adjuvant to interferon and ribavirin in naive patients with chronic hepatitis. Presented at the American Association for Study of Liver Diseases, 2002, Boston. (Abstract 101808).

61 Oniankitan O, Dusoux C, Challine D, Mallat A, Chevelier X, Pawlotsky Metal J. Infliximab therapy for rheumatic diseases in patients with chronic hepatitis B and C. J Rheumatol 2004:31:107-9.

62 Michel M, Duvoux C, Hezode C, Cherqui D. Fulminant hepatitis after infliximab in a patient with hepatitis $B$ versus treated for an adult onset stills disease. J Rheumatol 2003;30:1624-5.

63 Olivieri I, Padula A, Ciancio G, Salvarani C, Niccoli L, Cantini P. Persistent efficacy of tumor necrosis factor alpha blockade therapy in SAPHO. Arthritis Rheum 2003;48:1467-8.

64 Wagner AD, Andersen J, Jendro MC, Hulsemann J, Zeidler H. Sustained response to tumor necrosis factor alpha blockade agents in two patients with SAPHO syndrome. Arthritis Rheum 2002;46:1965-8. 